\title{
Research Articiz: Influence of nitrogen levels and chlormequat on nutrient status and nitrogen uptake by wheat
}

\author{
S.R. MEENA, V.S. KHAWALE, V.V. PATIL AND H.V. PAWAR
}

Article Chronicle:

Received :

19.07.2017;

Accepted :

03.08.2017

KEY WoRds:

Wheat, Chlormequat, Nitrogen uptake,

Nutrient status

SUMMARY : A field experiment was conducted during Rabi season of 2013-2014 at Agronomy Section Nagpur. The experiment was laid out in split plot design with three treatments of nitrogen levels under main plot viz., $\mathrm{N}_{1}-100 \mathrm{~kg} \mathrm{~N} \mathrm{ha}^{-1}, \mathrm{~N}_{2}-125 \mathrm{~kg} \mathrm{~N} \mathrm{ha}^{-1}, \mathrm{~N}_{3}-150 \mathrm{~kg} \mathrm{~N}^{-1}$ and four chlormequat levels as sub plot treatments viz., $\mathrm{C}_{0}-$ Control i.e. (no inoculation, no foliar application), $\mathrm{C}_{1}$ - Seed inoculation of chlormequat @ 1000 ppm, $\mathrm{C}_{2}$ - Foliar application of chlormequat @ 1000 ppm at maximum tillering stage and $\mathrm{C}_{3}$ - Seed inoculation of chlormequat @ 1000 ppm + foliar application of chlormequat @ 1000 ppm at maximum tillering stage, forming 12 treatment combinations replicated three times. Nitrogen uptake by crop was increased significantly with increase in levels of nitrogen. Total uptake of nitrogen was significantly more with application of $150 \mathrm{~kg} \mathrm{~N} \mathrm{ha}^{-1}$. After harvest available nitrogen content in soil was maximum with application of $150 \mathrm{~kg} \mathrm{~N} \mathrm{ha}^{-1}$ and Seed inoculation of chlormequat @ $1000 \mathrm{ppm}+$ foliar application of chlormequat @ 1000 ppm at maximum tillering stage recorded significantly more uptake of nitrogen.

How to cite this article : Meena, S.R., Khawale, V.S., Patil, V.V. and Pawar, H.V. (2017). Influence of nitrogen levels and chlormequat on nutrient status and nitrogen uptake by wheat. Agric. Update, 12(TECHSEAR-7) : 1937-1939; DOI: 10.15740/HAS/AU/12.TECHSEAR(7)2017/1937-1939. 